\title{
WATER EXPULSION AND PINGO FORMATION IN A REGION AFFECTED BY SUBSIDENCE
}

\author{
By R. C. Bostrom \\ (Department of Geology, University of Washington, Seattle, Washington, U.S.A.)
}

\begin{abstract}
Geophysical evidence indicates that the delta area of the Mackenzie River, Northwest Territories, is affected by tectonic subsidence. Pingos are of sparse occurrence in the Arctic as a whole but they occur in hundreds in the Mackenzie River delta.

In a region of subsidence, as recent sediments pass through the base of permafrost, compaction becomes possible. The resulting water expulsion produces an artesian head responsible for building pingos.

RÉsumé. Expulsion d'eau et formation de pingo dans une région soumise à la subsidence. Une évidence géophysique indique que la zone du delta de la Fleuve Mackenzie, Territoires du Nord-Ouest, est soumise à une subsidence tectonique. Les pingos sont rares pour l'ensemble de l'Arctique, mais ils existent par centaines dans le delta de la Fleuve Mackenzie.

Dans une région soumise à la subsidence, comme des sédiments récents passent à travers la base du permafrost, la compaction devient possible. L'expulsion de l'eau qui en résulte produit une source artésienne responsable de la formation des pingos.

Zusammenfassung. Wasserverdrängung und Pingobildung in einem Senkungsgebiet. Geophysikalische Befunde weisen darauf hin, dass das Deltagebiet des Mackenzie River, Northwest Territories, tektonischer Senkung unterliegt. Pingos kommen in der gesamten Arktis selten vor, im Mackenzie-River-Delta dagegen zu Hunderten.

In einem Senkungsgebiet wird eine Verdichtung möglich, da junge Sedimente unter die Grenze des Dauerfrostes absinken. Die damit verbundene Wasserverdrängung erzeugt artesischen Druck, der zum Wachstum von Pingos führt.
\end{abstract}

\section{INTRODUCTION}

It has been supposed that pingos fall genetically into two classes. The first is known as the opensystem or East Greenland class, in which hydraulic pressure having its origin in highlands bows up surficial strata into domes. The more numerous Mackenzie or closed-system class of pingo has been thought to owe its origin to expansion following the progressive downward freezing of sediment in a shoaling lake bed (Porsild, 1938).

As a result of an investigation to trace the course of the East Pacific Rise north of Vancouver (reported elsewhere), it has become evident that the Mackenzie River delta region is one of contemporary tectonic subsidence. The compaction behavior of sediments at the base of permafrost in such a region is discussed here. It would appear that in the Mackenzie River delta pingo formation is the result of the expulsion of water from layers below the freezing-point isotherm.

\section{Observations}

Upon his return from Franklin's second expedition to the Polar Sea Sir John Richardson (1828) described the flat alluvial country at the mouth of the Mackenzie River "from which there arise, abruptly, hills of an obtuse conical form, from one to two hundred feet above the general level". A map published by Mackay (1962) shows that in the Mackenzie River delta pingos number hundreds, forming the greatest known concentration of these features. Throughout most of the Arctic they are absent or of somewhat sparse local occurrence.

Recent geophysical investigations, not forming part of the present paper, have shown that the gravity field in the region of the Mackenzie River delta is of the form shown in Figure 1 . The region is seismically active. The delta area is separated from the recently uplifted area adjoining by transcurrent and normal faults.

In theory, the gravity anomaly at the mouth of a great river should be positive due to loading of the Earth's crust with sedimentary masses. The field shown in Figure I is explained as follows. The Bouguer high flanking the north end of the profile is due to crustal thinning beneath the waters of the Beaufort Sea. The regional high at the south end of the profile is a result of uplift of dense basement rocks. The intervening regional low is the expression of sedimentary porosity in an area of tectonic 


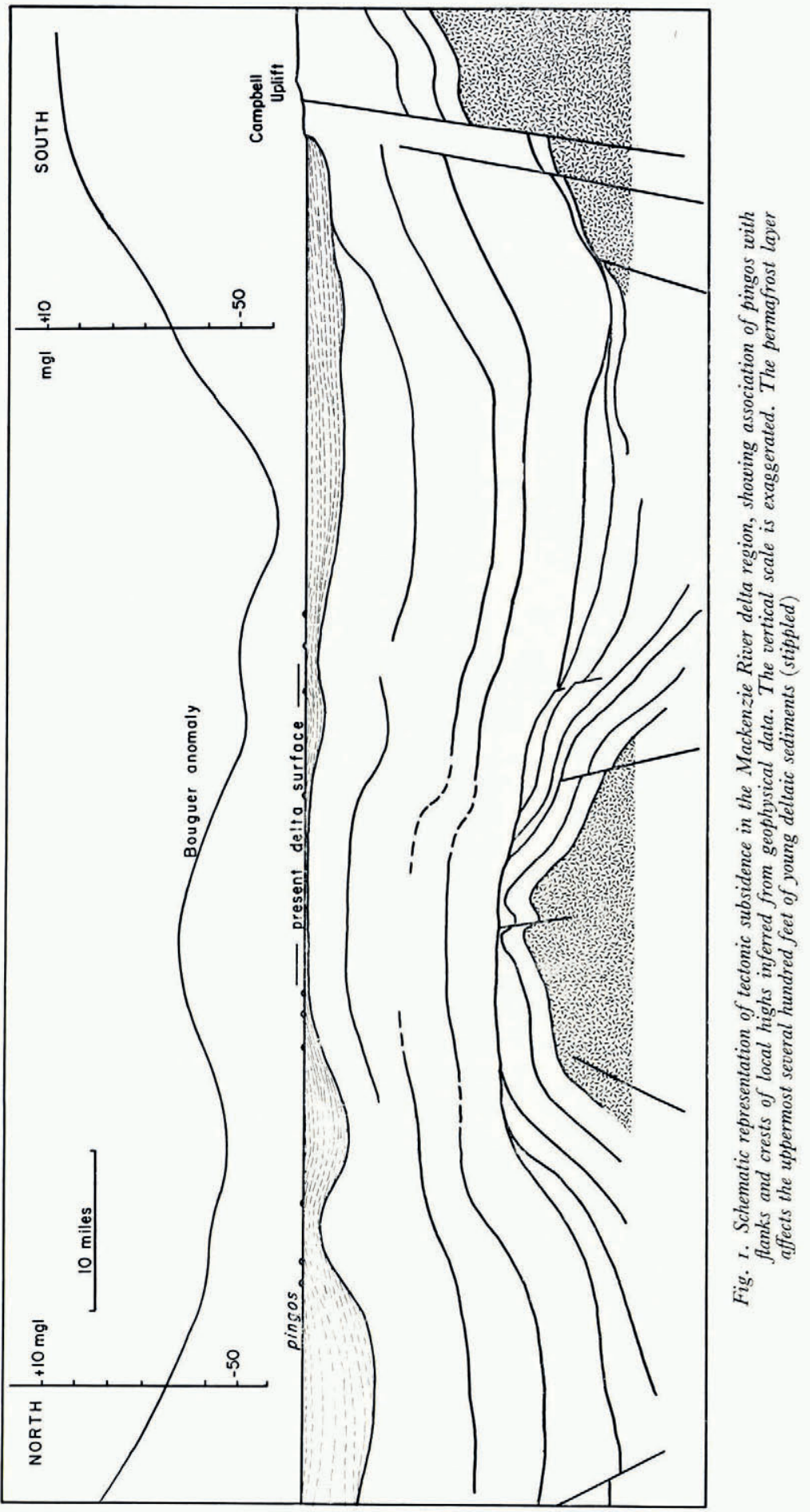


down-faulting. The highs within the regional low are associated with localities of less rapid subsidence overlying the up-tilted edges of blocks and local horst blocks.

It is found that pingo concentrations are associated with the regional gravity low, and within this low, not with the areas of lowest gravity reading (that is to say, of most rapid subsidence), but with the secondary gravity highs.

\section{HYPOTHESIS}

As a result of the observed relationship between pingo concentrations and areas of less rapid subsidence in a region subjected to tectonic down-warping, consideration was given to the effects to be expected at the base of a permafrost layer being depressed. In a subsiding layer, recently deposited sediments are at first not subject to compaction because they are saturated and frozen. However, as soon as the layer passes through the $o^{\circ} \mathrm{C}$. isothermal surface compaction becomes possible. The compaction which in a region not covered by permafrost takes place gradually, as material becomes buried under increasing overburden, is then caused to take place all at once through the withdrawal of support provided by interstitial ice.

The compaction, which can be expected to take place as a result of burial of recent sediments below some hundreds of feet of overburden, varies from a few per cent if the sediment is a sand to more than 75 per cent if the material is peat or sapropel. The result in a permafrost region subjected to subsidence is that a rigid impermeable layer, of the order of $300 \mathrm{ft}$. $(9 \mathrm{I} \mathrm{m}$.) thick in the delta of the Mackenzie River, is perched upon a layer newly thawed and surcharged with water.

It is not conceivable that such an unstable situation can persist. The fluid in the thawed layer subject to excess pore pressure tends to be expressed but it cannot (as in regions such as the delta of the Mississippi River) find its way directly to the surface. It is now hypothesized (Fig. 2) that the expelled water makes its way beneath the lower surface of permafrost to areas which are locally high and there makes its way upward to form pingos.

The association of pingos with ponds and marshes appears to be other than random. For reasons discussed below, it seems likely that pingo ponds owe their presence to the upward transport of heat by water seepage, and that they are not the primary agent in the formation of pingos.

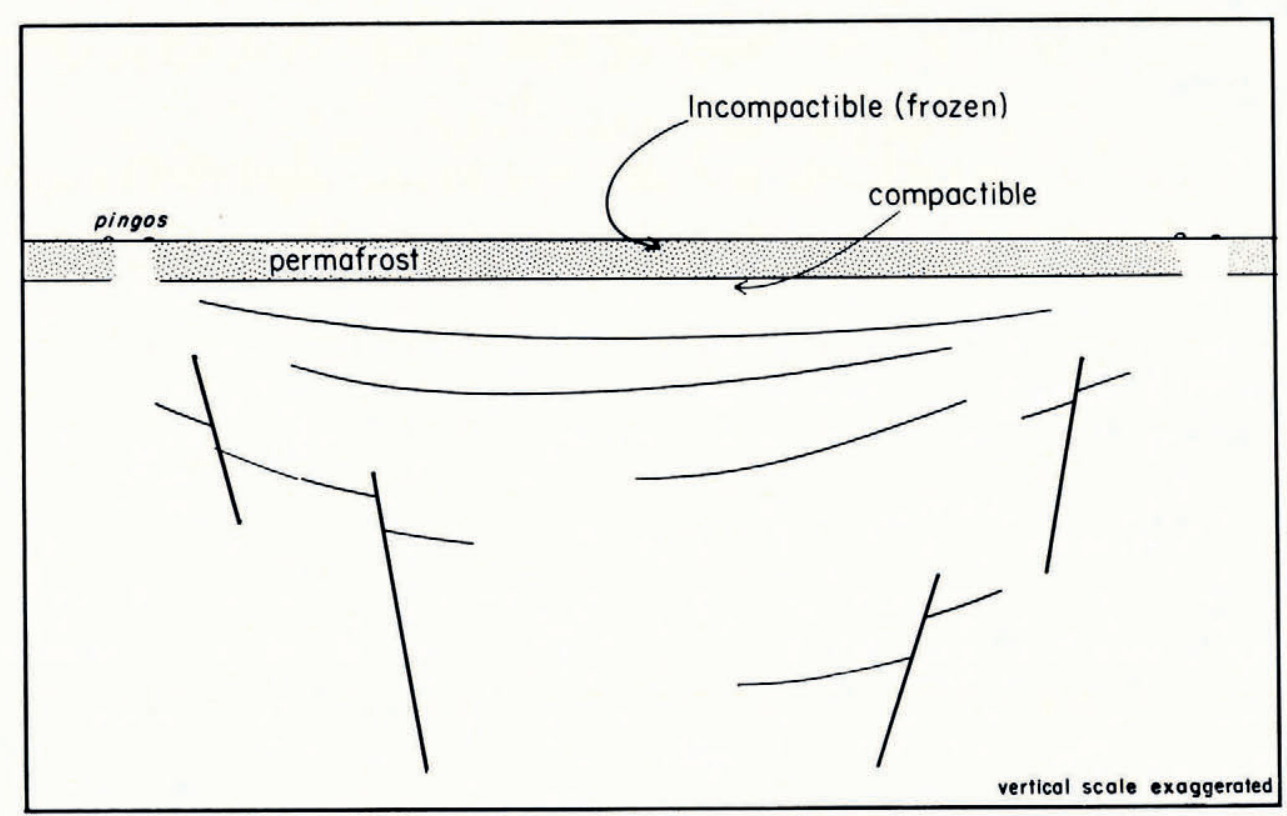

Fig. 2. Development of excess pore pressure beneath permafrost in a region affected by subsidence 
ANALysis

Porsild (1938) has remarked regarding pingo formation in level ground that "conditions favorable to the setting up of hydraulic pressure cannot well be conceived, and we must consider a local upheaval". Gussow (I954) accounted for pingos in terms of the mechanism responsible for the up-doming of salt and anhydrite, requiring the presence of deeply buried masses of ice.

The hydraulics of a situation typical of the Mackenzie River delta area is shown in Figure 3. In the example shown, regional subsidence is assumed and the permafrost layer is $300 \mathrm{ft}$. (91 m.) thick. The freezing-point surface at the base of the permafrost is slightly depressed, and relative to the layer moves upward as sediment is added at the surface by the waters of the Mackenzie River. The height range of pingos in this region is 10 to $160 \mathrm{ft}$. (3 to $49 \mathrm{~m}$.). The example shown is $100 \mathrm{ft}$. $(30 \cdot 5 \mathrm{~m}$.) high.

Immediately below the $0^{\circ} \mathrm{C}$. isothermal surface in the region of subsidence, pore pressure through withdrawal of the mechanical support hitherto provided by ice is $300 \mathrm{ft}$. (9I m.) multiplied by the density of the impermeable frozen mass overlying it. In recent sediments, dependent upon whether these are organic or arenaceous, densities range between $I_{1} I_{\text {and }} \mathrm{I} \cdot 7 \mathrm{~g} . / \mathrm{cm} .^{3}$. In the example, the density selected is $\mathrm{I} \cdot 33 \mathrm{~g} . / \mathrm{cm} .^{3}$, producing a pore pressure of $12,192 \mathrm{~g} . / \mathrm{cm} .^{2}$.

In a locality having fluid access to the surface, however (as below a holiday in the permafrost), pore pressure is represented by the hydraulic head of water. This amounts to $300 \mathrm{ft}$. (9I m.) multiplied by a density of $\mathrm{I} \mathrm{g} . / \mathrm{cm} .^{3}$, which is to say $9, \mathrm{r} 44 \mathrm{~g} . / \mathrm{cm}^{2}$.

The difference between the pressures noted is available to produce a flow of water to the surface, having at the surface an excess head of $3,048 \mathrm{~g} \cdot / \mathrm{cm} .^{2}$. This represents roo $\mathrm{ft}$. $(30 \cdot 5 \mathrm{~m}$.) of water, in conformity with the height above surface attained by the Mackenzie River delta pingos. At the surface of a section thousands of feet thick the flow of expelled water will continue for an extended period.

There remains to be considered the part played by pingo ponds. Müller (1959) has pointed to the association of pingos with ponds and the residue of ponds, attributing with Porsild the formation of pingos to the expulsion of water from a pond bed due to its becoming frozen. This explanation seems not to account for the existence of a permafrost holiday below ponds in the first place. It is uncertain that insolation and density layering in a pond can between them account for the penetration of thawing to the base of permafrost in a region well within the permafrost belt. It is tempting, in an area underlain by water above the freezing point and having an artesian head, to suppose that the springs and ponds

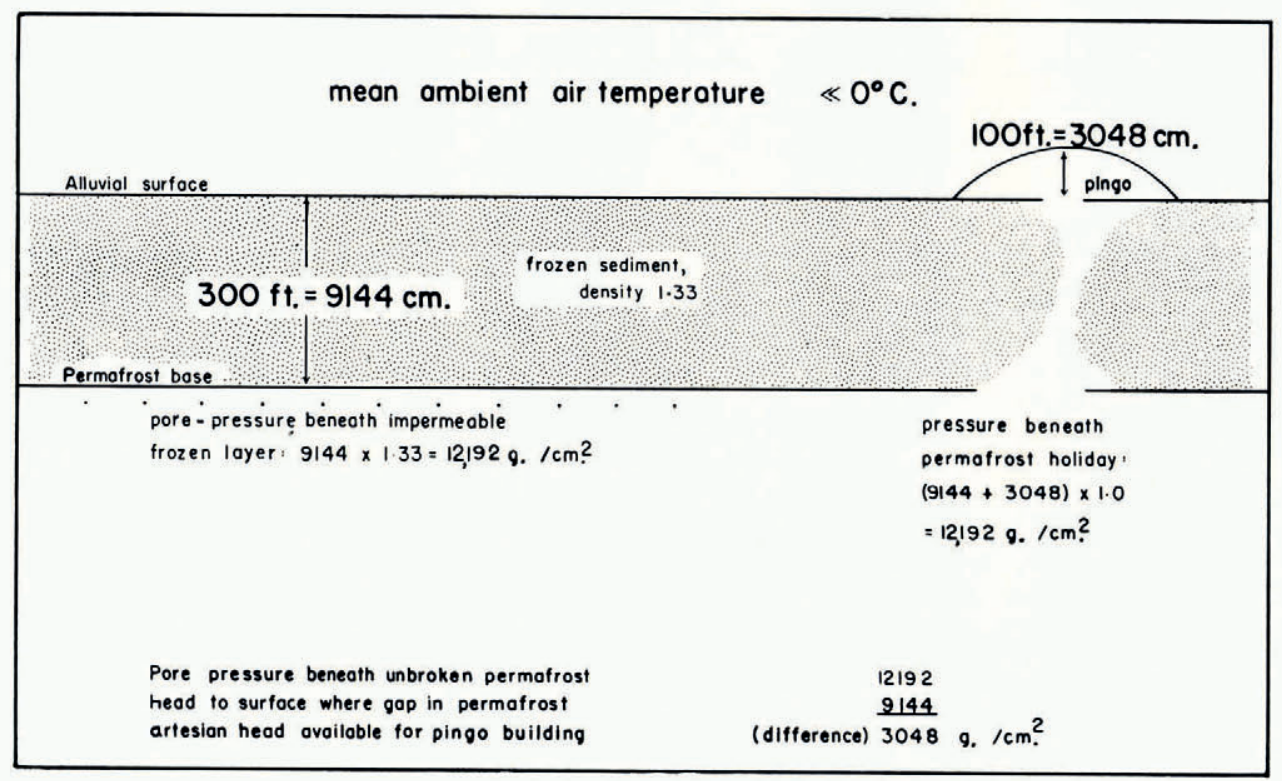

Fig. 3. Artesian head resulting from density difference in a column of frozen sediment and a column of water 
dotting the landscape owe their presence and the existence of underlying taliks to the upward transport of heat by water. The channels permitting percolation may have originated in faulting, taking place as a result of flexure in the permafrost layer; once started, the upward seepage of water could be expected to maintain and enlarge the thawed area. Alternatively, holidays in the permafrost mantle may have been initiated by river channels. When a pond shoals, permitting freezing to the bottom to take place in winter, continued upward percolation of artesian water leads to up-doming and the formation of a pingo.

\section{Conclusions}

The following points summarize the conclusions:

a. In pingo building, the energy source is gravity.

b. Gravitational energy is mobilized by the compaction of a sedimentary section.

c. The artesian head generated is represented by the difference in density between a water column and the equivalent column of water-filled sediments.

d. Pingo concentrations, such as those at the mouth of the Mackenzie River, are the result of tectonic or compaction subsidence in the presence of permafrost.

e. Pingo ponds are consequent. A permafrost holiday is created and maintained by the upward seepage of water transporting heat.

f. The Mackenzie River pingos belong to the hydraulic class.

The tectonic subsidence now seen at the mouth of the Mackenzie River is genetically connected with the presence in this area of the Franklin Rise, an extension of the East Pacific Rise. A corresponding segment of the ocean-ridge system passes beneath the Asiatic continent at the mouth of the Lena River. It would be interesting to know whether pingo formation in association with tectonic subsidence takes place at the mouth of the Lena River.

MS. received 26 July 1966

\section{REFERENCES}

Gussow, W. C. 1954. Piercement domes in Canadian Arctic. Bulletin of the American Association of Petroleum Geologists, Vol. 38, No. 10, p. 2225-26.

Mackay, J. R. 1962. Pingos of the Pleistocene Mackenzie Delta area. Geographical Bulletin (Ottawa), No. 18, p. $2 \mathrm{I}-63$.

p. 21-63.
Müller, F. 1959. Beobachtungen über Pingos. Detailuntersuchungen in Ostgrönland und in der Kanadischen Arktis. Meddelelser om Gronland, Bd. $153, \mathrm{Nr}$. 3 .

Porsild, A. E. 1938. Earth mounds in unglaciated Arctic northwestern America. Geographical Review, Vol. 28, No. 1, p. $46-58$.

Richardson, Sir J. 1828. Appendix I. Topographical and geological notes. (In Franklin, Sir J. Narrative of a second expedition to the shores of the Polar Sea. London, John Murray, p. i-lviii.) 